\title{
Teknologi Terbaru Severe Plastic Deformation (SPD) Untuk Aplikasi Perangkat Kemiliteran
}

\begin{abstract}
Agus Pramono ${ }^{1}$
Abstrak: Teknologi severe plastic deformation (SPD) atau deformasi plastis menyeluruh merupakan proses pembentukan logam di mana strain plastik ultra-besar dimasukkan ke dalam perangkat cetakan dan mesin pada proses pengerjaan logam. Hal ini dimaksutkan untuk menciptakan logam berbutir ultra-halus / Ultrafine Grained (UFG), sehingga sifat dari logam tersebut akan meningkat secara drastis. Ada tiga jenis metode dalam teknologi SPD; Equal Channel Angular Pressing (ECAP), High PressureTorsion (HPT) dan Accumulative Roll Bonding (ARB). Serta beberapa teknologi terbaru yang dikembangkan di beberapa negara seperti Korea, Jerman, Jepang, Cina, Rusia dan Estonia. Beberapa metode SPD terbaru dikembangkan untuk memperingkas proses agar mudah diterapkan dalam industri. Dalam penerapan perangkat kemiliteran, teknologi yang dibutuhkan harus mampu berubah menjadi kekuatan yang lebih mobile, survivable serta mematikan sekaligus memberi dampak yang lebih baik terhadap lingkungan (tidak menimbulkan efek polusi). Ada banyak tantangan teknis yang belum diatasi. Akibatnya, produsen potensial logam dengan teknologi terbaru SPD masih memerlukan rantai proses untuk penerapan aplikasi. Mereka juga khawatir tentang kelangsungan hidup komersial logam proses SPD tersebut, yang mana dalam operasional sangat tergantung pada permintaan dari pasar potensial dan biaya produksi. Keduanya adalah faktor yang sulit untuk dievaluasi karena rendahnya ketersediaan logam UFG dan ketidakpastian mengenai teknologi SPD. Hal ini telah mendorong eksplorasi aplikasi untuk peralatan militer - khususnya berbasis material komposit, seperti; helikopter, tank, panser dan baju besi serta helm militer untuk pasukan militer dalam bertempur.
\end{abstract}

Kata Kunci: Severe Plastic Deformation, ECAP, HPT, ARB, dan perangkat kemiliteran (Alutsista) 


\section{PENDAHULUAN}

Teknologi Severe Plastic Deformation (SPD) / Deformasi Plastis Menyeluruh merupakan sebuah proses pembentukan logam di mana strain plastik ultra-besar dimasukkan ke dalam perangkat proses, dalam rangka menciptakan logam yang berbutir ultra-halus (Ultrafined Grained/UFG), sehingga sifat dari logam tersebut akan meningkat secara drastis. Tujuan utama dari proses SPD adalah untuk menghasilkan kekuatan tinggi dan bagian ringan dengan mencapai harmoni lingkungan [1]. Teknologi SPD terdiri dari beberapa jenis proses, proses yang paling terkenal ada tiga jenis yaitu; Equal Saluran Sudut Menekan (EqualChannelAngularPressing/ECAP),

Tekanan Tinggi Torsi (HighPressureTorsion/HPT) dan akumulatif Gulung (AccumulativeRollBonding/ARB) [2].

Baru-baru ini, banyak penelitian yang dikembangkan oleh beberapa ilmuwan untuk memperoleh struktur-mikro ultra-halus pada butir dengan skala nano. Yang mana hal ini telah dilakukan oleh beberapa peneliti dengan menggunakan berbagai proses $S P D$, seperti ECAP, HPT dan ARB. Dalam penelitian $S P D$ yang telah dilakukan oleh $\mathrm{R}$. Z. Valiev [3] dan Kris A. Darling [4] telah berhasil mensintesis bahan untuk keperluan peralatan militer, dalam karya-karya-nya, mereka telah berhasil meningkatkan sifat material logam untuk diaplikasikan dalam peralatan militer seperti perangkat spare part komponen kendaraan tempur. Beberapa teknik SPD, seperti ECAP, HPT dan ARB, telah dipelajari secara ekstensif selama dua dekade terakhir, karena kemampuan teknologi tersebut untuk memproduksi berbagai logam massal dan paduan dengan butir ultra-halus (UFG) dengan struktur-mikro yang seragam [1-5].

Dari sudut pandang teknologi, proses SPD telah sukses melampaui dua hambatan utama. Pertama tingkat beban yang secara langsung mempengaruhi desain alat,

${ }^{1}$ Peneliti Teknologi SPD dan Staf Pengajar (Dosen) Teknik Metalurgi Universitas Sultan Ageng Tirtayasa Cilegon - Banten dan Rais Syuriah (Ketua Dewan Pembina) Pengurus Cabang Istimewa Nahdlatul Ulama Federasi Rusia dan Negara-Negara Eropa Utara (FREU). terutama dalam dimensi besar bahan serta yang kedua merupakan sifat mampu bentuk dari material yang harus dikaji lebih jauh sehingga dapat kompatibel dengan tingkat deformasi berulang yang besar. Sampai saat ini belum ada kriteria yang menjamin kesuksesan Teknologi SPD dalam beberapa aplikasi material. Distribusi tegangan yang seragam akan dapat menentukan keberhasilan produk teknologi SPD [6]. Jika percobaan SPD mengacu pada tahap yang sesuai dari tahapan proses SPD yang tepat maka akan menghasilkan bahan dengan sifat yang unik dan butiran struktur mikro ultrahalus. Langkah-langkah proses dijelaskan dalam metode eksperimental dan proses dapat dilihat pada Gambar 1. Dalam logam konvensional proses pembentukan seperti rolling, penempaan dan ekstrusi, strain plastik yang dikenakan terlalu rendah serta ketebalan dan diameter menjadi sangat tipis dan tidak cocok untuk diaplikasikan untuk bagan struktural. Hampir semua proses SPD telah memberlakukan regangan plastik yang lebih baik. Dalam rangka untuk memaksakan suatu strain sangat besar pada logam massal tanpa mengubah bentuk maka banyak proses SPD telah dikembangkan $[1,2]$.

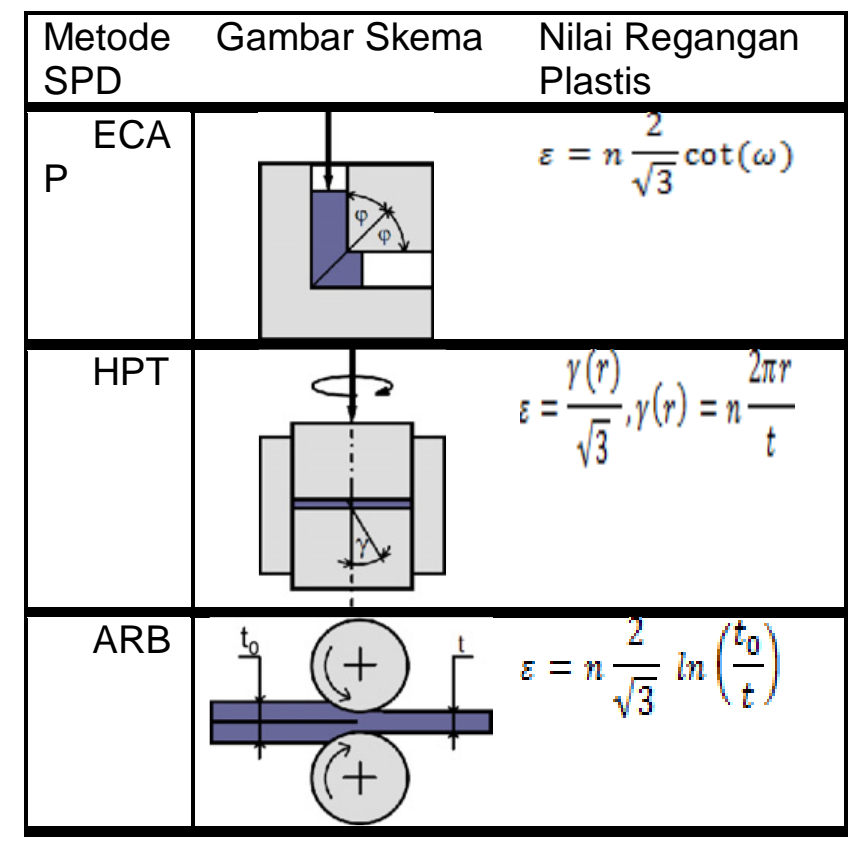

Gambar. 1. Macam - macam Proses SPD yang telah dikembangkan [1]

Dari aspek material, keramik sebagai bahan penguat dan logam sebagai bahan matriks pada penerapan material berbasis komposit merupakan gabungan dua sifat yang berbeda untuk menjadi bahan komposit dengan sifat yang unik [6-7] komposit matriks logam 
(MetalMatrixComposite/MMC) secara signifikan menurunkan sifat mampu bentuk dan keuletan pada bahan paduan. Berdasarkan model geometris, untuk mencapai distribusi partikel yang homogen dalam MMC secara teoritis jarak antarpartikel harus sama atau lebih tinggi dari ukuran serbuk pada matriks jika bahan dasarnya metalurgi serbuk, sehingga memperkuat ukuran butir lebih halus dari matriks sehingga akan memudahkan proses difusi pada struktur mikro ketika material diproses dengan teknologi SPD [8]. Difusi dalam material komposit dengan proses teknologi SPD yang disebabkan oleh deformasi penekanan akan membentuk batas butir energi yang tinggi, dengan suhu panas maka segregasi dan difusi akan menuju pada batas butir.

Fenomena ini mengakibatkan difusi terjadi dalam kondisi non-ekuilibrium [9]. Komposit logam matriks (MMC) berada di bawah perhatian untuk banyak aplikasi di ruang angkasa, industri otomotif dan peralatan kemiliteran. MMC, sedang dipertimbangkan sebagai kelompok bahan canggih baru ringan, kekuatan tinggi, koefisien ekspansi termal rendah dan ketahanan aus yang baik [10]. Berdasarkan fenomena ini banyak penelitian berbasis material komposit dengan penggunaan teknologi SPD diterapkan untuk aplikasi perangkat kemiliteran. Seperti yang telah dilakukan oleh R. Z. Valiev [3], K. A. Darling [4] dan Terence Langdon yang penerapannya oleh Military Research untuk Bahan Penelitian,Transformasi Tempur Tanah Melalui Teknologi Baru [11] untuk membuat aplikasi komposit untuk peralatan kemiliteran

\section{METODOLOGI TEKNOLOGI SPD}

Teknologi SPD pertama kali dipelopori oleh dua ilmuwan Rusia yaitu Vladimir Seagal dengan EqualChannelAngular Extrusion ECAE) dan Ruslan Valiev melalui Metode HighPressureTorsion (HPT) yang sebelumnya digali oleh Percy Bridgman. Setelah mengembangkan HPT Ruslan Valiev menyempurnakan metode ECAE yang dieksplortasi menjadi lebih aplikatif dengan nama EqualChannelAngularPressing (ECAP), pada prinsipnya proses ECAE dan ECAP sama, hanya dibedakan oleh mesin penggerak, ECAE menggunakan mesin konvensional sedang ECAP menggunakan mesin hidrolis/pneumatis. Pada tahun 1990 sampai tahun 2000 beberapa aplikasi sudah diterapkan dalam skala industri, setelah itu beberapa Ilmuwan dunia melanjutkan sintesa ke tahap pengembangan teori untuk menunjang teknologi SPD. Pada tahun 1998 ilmuwan Jepang yaitu Nobuhiro Tsuji beserta timnya mengembangkan material berbentuk plat dengan proses AccumulativeRollBonding (ARB).

Melalui beberapa pertemuan ilmiah seperti konferensi internasional, beberapa ilmuwan teknologi SPD membangun jaringan untuk membuat teknologi tersebut lebih aplikatif dan selanjutnya pihak militer Amerika Serikat (U.S Army) bekerjasama dengan ilmuwan Rusia yang diketuai oleh Prof. Ruslan Valiev (Institute of Physics of Advanced Materials, Ufa State Aviation Technical University) telah mengembangkan teknologi manufaktur terbaru Severe Plastic Deformation (SPD).

\subsection{Equal Channel Angular Pressing .}

EqualChannelAngularPressing (ECAP) merupakan proses manufaktur logam yang memiliki kemampuan untuk memperkenalkan perbaikan yang signifikan dalam butir sampel massal besar. Biasanya, mengurangi ukuran butir ke tingkat sub-mikrometer, dan dengan demikian menghasilkan bahan yang mampu untuk memberikan sifat fisik dan mekanik yang tidak biasa. ECAP merupakan tegangan tekan dan tarik dalam cetakan untuk menghasilkan produk dengan deformasi parah sehingga akan dihasilkan butir halus yang memperkuat sifat mekanik bahan [12].

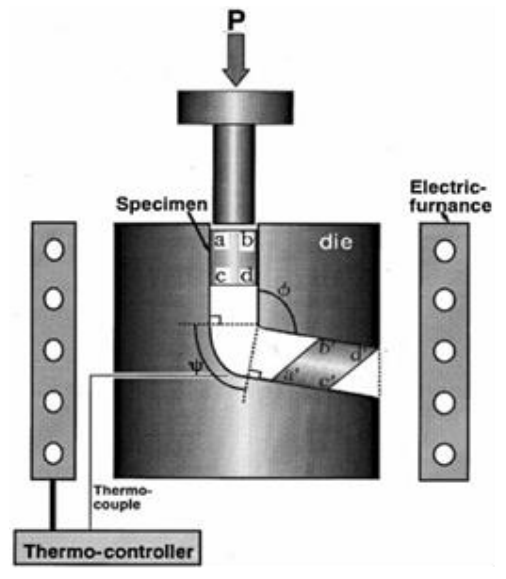

Gambar 2. Proses llustrasi ECAP [2]

ECAP adalah teknik pengolahan sangat menarik karena beberapa alasan. Pertama, dapat diterapkan untuk billet cukup besar sehingga ada potensi untuk memproduksi bahan-bahan yang dapat diaplikasikan. 
Kedua, itu adalah prosedur yang relatif sederhana yang mudah dilakukan pada berbagai paduan dan komposit. Ketiga, ECAP dapat dikembangkan dan diaplikasikan pada material dengan struktur kristal yang berbeda dan banyak bahan mulai dari paduan presipitasi yang mengeras pada intermetallics dan komposit logam terutama matriks dalam komposit. Keempat, homogenitas yang wajar dicapai melalui sebagian besar billet sebagai penekanan yang menyediakan pressing yang terus menerus sehingga menghasilkan strain yang cukup tinggi. Kelima, proses dapat ditingkatkan scale-up untuk menekan pada sampel yang relatif besar dan merupakan potensi untuk pengembangan ECAP untuk digunakan dalam prosedur pengolahan logam komersial [2]. Sifat deformasi yang dikenakan adalah gaya geser sederhana yang terjadi sebagai sampel melewati cetakan dalam kompresi mesin seperti ditunjukkan secara skematis pada Gambar 2 [1-2].

\subsection{High Pressure Torsion}

HighPressureTorsion (HPT) adalah proses deformasi antara gaya kompaksi dengan gaya torsi dari sebuah cincin pendek dengan bentuk kerucut yang berada pada virtual kontak bertemu pada sumbu aparatur seperti ditunjukkan pada Gambar 3. Pada bagian muka terdapat pencocokan kerucut dari spesimen cincin yang dibatasi dari segala arah yang menciptakan kondisi yang lebih dekat dengan tekanan hidrostatik. Ruslan Valiev telah melakukan proses HPT dengan menggunakan perangkat di bawah tekanan tinggi seperti yang ditunjukkan pada Gambar 3. Pada perangkat ini, disk yang sangat tipis dikompresi dalam cetakan tertutup oleh tekanan yang sangat tinggi. Torsi yang disediakan oleh pukulan penekanan dengan gesekan kontak pada antarmuka antara pukulan dan disk.

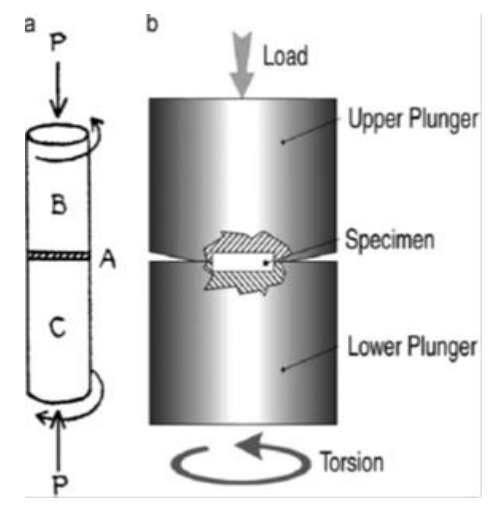

Gambar. 3. Perangkat proses HPT [1].

Metode ini memiliki kelemahan yang menggunakan spesimen dalam bentuk cakram yang relatif kecil dan tidak tersedia untuk produksi bahan secara massal. Kerugian lain adalah bahwa strukturmikro yang dihasilkan tergantung pada penerapan tekanan serta lokasi dalam disk [1]

\subsection{Accumulative Roll Bonding}

AccumulativeRollBonding

dikembangkan oleh Saito dan N. Tsuji pada Group of Physical Property of Materials Laboratory of Structure and Property of Materials. Dept. of Materials Science and Engineering Kyoto University Jepang. Prinsip dari proses ARB diwakili secara sistematis pada Gambar 4, pada penumpukan lembar logam pada proses konvensional ikatan roll yang berulang pada proses. Pertama, strip rapi ditempatkan di atas strip lain. Antarmuka dari dua strip permukaan terlebih dahulu dibersihkan dengan cairan aseeton dalam rangka untuk meningkatkan kekuatan ikatan. Dua lapisan digabungkan bersama oleh proses roll, seperti dalam proses roll-ikatan konvensional. Kemudian, panjang dari bahan digulung dipotong dibagi menjadi dua bagian. Kemudian strip yang dipotong permukaannya dibersihkan, ditumpuk dengan roll-berikat. Pada prinsipnya prosedur ini dapat diulang tanpa batas, sehingga regangan plastik yang sangat besar dapat diterapkan pada bahan logam paduan maupun komposit.

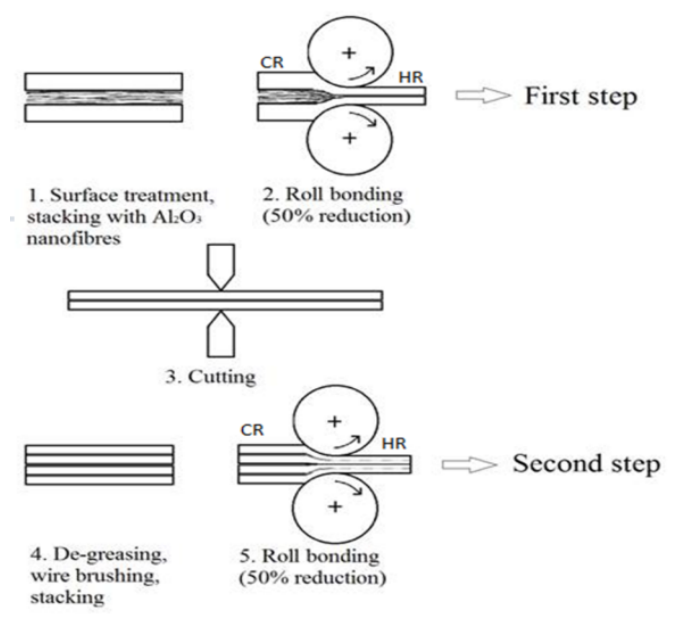

Gambar 4. Tahapan proses akumulatif roll-ikatan (ARB) [1].

Dalam ARB, bahan digulung dan dipotong, ditumpuk menjadi ketebalan awal 
dan kemudian dilakukan proses roll. Oleh karena itu, strain yang dicapai besar. Proses ini bisa dilakukan secara berulang dan tidak terbatas pada penekanan pengerolan. Untuk mendapatkan bahan massal maka lembar ditumpuk terikat selama pengerolan secara bersamaan. Untuk mencapai ikatan yang baik, perawatan permukaan, seperti degreasing dan penyikatan dengan kawat, permukaan lembaran dibersihkan sebelum ditumpuk. Roll pada suhu tinggi menguntungkan untuk penggabungan kemampuan kerja pada material bahan yang di proses roll, meskipun suhu terlalu tinggi akan menyebabkan rekristalisasi dan membatalkan akumulasi regangan. $[1,13]$.

\section{TEKNOLOGI SPD UNTUK APLIKASI ALUTSISTA}

Teknologi SPD berkembang sejalan dengan perkembangan material, baik secara proses manufaktur ataupun dari aspek bahan/material. Perkembangan dari teknologi bahan dan material saat ini mengarah pada material komposit dengan menggunakan aluminium sebagai matriks dan keramik sebagai penguat, yaitu alumina dan silikon karbida. Seperti yang telah dilakukan oleh Bing Q. Hana dan Terence G. Langdon dalam karyanya [14] ECAP pada AA6061 + 10 vol. $\% \mathrm{Al}_{2} \mathrm{O}_{3}$. Proses ini efektif dalam meningkatkan ukuran butir material dari 35 $\mu \mathrm{m}$ mencapai $300 \mathrm{~nm}$. Pengolahan ECAP dilakukan pada suhu $533 \mathrm{~K}$ dengan menggunakan cetakan padat yang telah dibengkokkan pada saluran internal melalui sudut geser, $\Phi$, dari $90^{\circ}$ dan sudut $20^{\circ}$ pada lintasan. Proses ECAP menghasilkan sifat mekanik yang baik dalam komposit termasuk perpanjangan $\sim 320 \%$. Dalam studi lain [15] AA6061-10 \% SiC dan Al6061 - $20 \% \mathrm{Al}_{2} \mathrm{O}_{3}$ serbuk metalurgi (P/M) dengan distribusi partikel yang terdistribusi dalam kondisi fabrikasi yang dikenai torsi tekanan tinggi (HPT) pada suhu kamar. Untuk HPT, disk dengan diameter $8 \mathrm{~mm}$ dan ketebalan, t, dari $0,8 \mathrm{~mm}$ dipotong tegak lurus dengan sumbu ekstrusi (Gambar 3). Spesimen yang dikenakan HPT pada tekanan sebesar $5 \mathrm{GPa}$ pada kondisi suhu ruang. Jumlah putaran, $n$, dipilih untuk mencapai strain setara tertentu pada radius, $r$, dari $3 \mathrm{~mm}$, menurut hubungan spesimen $\mathrm{AA6061-20 \%} \quad \mathrm{Al}_{2} \mathrm{O}_{3} \quad \mathrm{MMC}$ yang cacat strain setara dengan $1,4,16,64,256$, dan 512 pada radius $3 \mathrm{~mm}$ HPT. Hasil dalam penelitian ini adalah; Difusi dan partikel yang padat dengan cluster yang berbeda selama HPT, cluster partikel difusi melunak, juga homogenisasi yang terjadi serta declustering dari kelompok partikel padat yang terjadi melalui mekanisme debonding partikel dari permukaan cluster partikel tanpa deformasi cluster partikel [15].

Material komposit dengan proses ARB membutuhkan siklus yang panjang untuk meningkatkan properties dari material [16]. Siklus ARB meningkatkan lapisan partikel matriks yang menyebabkan generasi memanjang kelompok padat. Pada strain yang lebih tinggi, ukuran cluster memanjang mengurangi sementara keseragaman dan kebulatan peningkatan bahan. Perubahan struktur mikro ini menyebabkan peningkatan kekerasan, kekuatan dan perpanjangan selama proses ARB. Umumnya, sifat mekanik komposit logam lebih baik dari pada logam tanpa paduan, pada siklus yang sama proses ARB menunjukkan bahwa, partikel penguat (matriks) dalam bentuk cluster seragam tersebar meningkatkan secara bersamaan antara kekuatan dan ketangguhan dari logam selama proses ARB [15-16].

Penelitian terkait material komposit telah menunjukkan perkembangan yang luar biasa, seperti aplikasi untuk armor yang menjadi aktivitas di Laboratorium Penelitian Angkatan Darat. Kantor Menteri Pertahanan, Direktorat Pertahanan Penelitian dan Rekayasa (DDR \& E) Amerika Serikat. The AMPTIAC Quarterly yang mana telah melakukan suatu pendekatan untuk mengurangi berat komponen dan kompleksitas sistem sehingga mampu mengembangkan bahan multifungsi yang menggabungkan dua atau lebih dari fungsi utama. Peneliti angkatan darat memiliki banyak program yang berlangsung, yang mengarah pada teknologi yang mengeksploitasi konsep tersebut. Sebuah upaya untuk pengembangan teknologi lainnya juga sedang diperiksa untuk dikembangkan sebagai generasi baru yang lebih ringan, bahan kinerja yang lebih tinggi diperlukan untuk meningkatkan efektivitas pertempuran perang [17]. Seperti yang akan dikembangkan oleh militer Rusia dengan transformasi organisasi dan peralatan (TOE) menuju modernisasi angkatan bersenjata dengan target selesai pada tahun 2020 [18]. Teknologi yang dibutuhkan harus berubah menjadi kekuatan yang lebih mobile, survivable, dan mematikan sekaligus menjadi 
layanan yang lebih baik terhadap lingkungan. Ada banyak tantangan teknis yang belum diatasi. Tujuan dari angkatan darat tidak hanya untuk "menyesuaikan" dengan teknologi melainkan mengantisipasi lintasan dan evolusi teknologi strategis, dengan demikian pengembangan sarana baru yang efektif untuk mengalahkan ancaman yang muncul dan mempertahankan keuntungan taktis yang unggul. Kemajuan sistem komposit pada dasarnya dua kali lipat: pertama adalah pengembangan serat fundamental baru, yaitu resin, dan lainnya adalah "penyusun" bahan. Yang kedua adalah integrasi bahan yang tersedia dalam komposit serta solusi bahan multifungsi yang secara signifikan meningkatkan sifat /kemampuan bahan (misalnya, baju besi struktural massal yang efisien). Beberapa aplikasi ada pada Gambar 5. Dalam rangka untuk memenuhi persyaratan dari transformasi angkatan darat, bahan yang dipilih harus mampu memecahkan sejumlah masalah sistem, yaitu berat yang efisien dan hemat biaya. Kemampuan ikatan komposit memungkinkan desainer dan engineer untuk memaksimalkan kinerja pada berat yang minimal pada komponen. Selain itu, kemampuan komposit untuk melakukan beberapa fungsi sebagai sistem materi yang menawarkan fleksibilitas untuk memaksimalkan efisiensi desain. Sebelumnya angkatan darat telah dipisahkan oleh beberapa persyaratan balistik dan struktural; sistem komposit sekarang menggabungkan dua persyaratan dalam aplikasi tertentu. Upaya saat ini difokuskan pada menggabungkan kekuatan, sensorsuite, komunikasi, dan pemantauan efek kesehatan dengan elemen komposit struktural. Satu-satunya cara untuk menyelesaikan tugas ini adalah untuk mengambil pendekatan holistik untuk mengembangkan sistem proses pembuatan komposit terutama untuk aplikasi peralatan angkatan darat $[11,18]$.

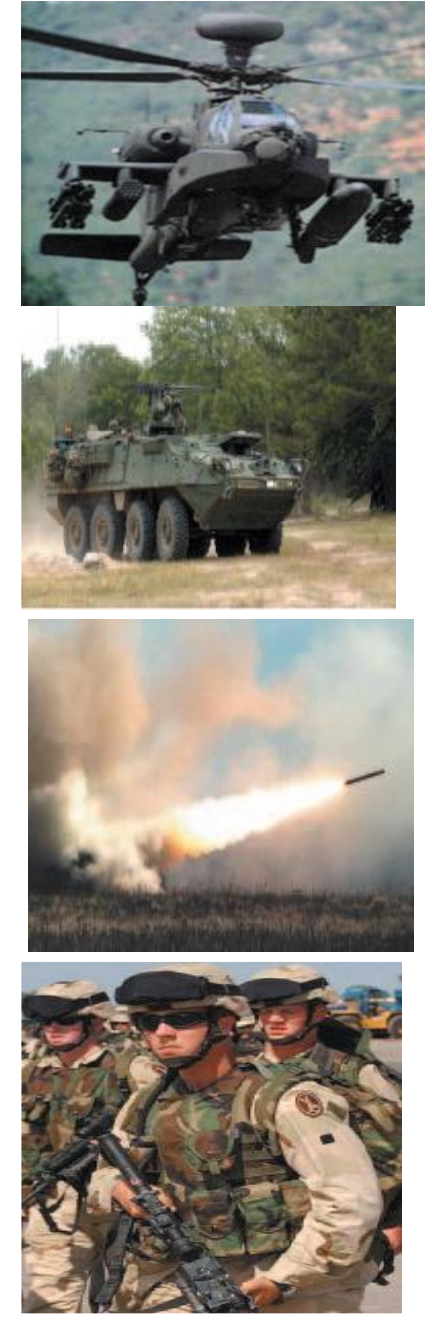

Gambar 5. Pengembangan Teknologi SPD untuk Aplikasi Alutsista

Sifat-sifat logam diproses oleh SPD menunjukkan kekuatan tinggi, keuletan dan karakteristik kemampuan untuk menahan kelelahan terhadap logam yang digunakan sebagai bahan struktural karena sifat tersebut. Dalam prakteknya, meskipun berbagai sifat mekanik dan fisik meningkat namun logam UFG yang diproduksi massal masih terbatas oleh penyerapan bahan dasar oleh industri. Ada beberapa alasan untuk ini; satu adalah kurangnya kesadaran industri UFG logam. Hal ini dikarenakan sejumlah besar akademisi yang terlibat dalam penelitian tentang SPD dan logam UFG masih terbatas. Alasan lain adalah kelangkaan UFG sampel dengan kesesuaian ukuran untuk percobaan industri; yang dihasilkan oleh laboratorium biasanya terlalu kecil karena mereka dimaksudkan untuk pengamatan metalurgi atau pengujian mekanik dasar sehingga terkendala dalam metode aplikasinya. Sehingga masih belum jelas yang mana dari berbagai metode SPD berbasis laboratorium akan muncul sebagai 
yang paling tepat untuk pelaksanaan industri / aplikasi

Akibatnya, produsen potensial logam UFG ragu berkomitmen untuk metode aplikasi tertentu. Mereka juga khawatir tentang kelangsungan produk komersial logam hasil UFG, yang mana tergantung pada permintaan dari pasar potensial dan biaya produksi. Keduanya sulit untuk menilai karena rendahnya ketersediaan logam UFG dan ketidakpastian mengenai teknologi SPD. Ada juga kurangnya pengetahuan tentang pengolahan pasca-SPD atau membentuk logam UFG dalam ranah aplikasi. Namun demikian, ada beberapa aplikasi yang, dengan tingkat tinggi probabilitas, akan memimpin pengenalan logam UFG ke pasar komersial. Awalnya, aplikasi tersebut mungkin berada pada peluang pasar yang memproduksi volume rendah produk khusus (misalnya targetsputtering). Langkah selanjutnya akan menjadi pasar volume menengah dengan penekanan diletakkan pada kinerja produk daripada harga. Industri pertahanan bisa mendapatkan keuntungan dari dua aplikasi skala besar logam UFG, sangat penting untuk mengurangi konsumsi bahan bakar, kecepatan yang lebih tinggi, kemampuan manuver yang lebih baik, jangkauan operasi lagi dan transportasi udara dari kendaraan ke lokasi terpencil [1].

\section{PROSES PENDEKATAN TEKNOLOGI KOMPOSIT TERINTEGRASI}

Ada tiga bidang yang muncul yang secara signifikan bisa membentuk masa depan proses pembuatan sistem perangkat kemiliteran, khususnya angkatan darat. Pertama adalah pengembangan solusi bahan multifungsi untuk mengatasi berat dan volume kendala sistem serta desain masa depan. Tantangan penting adalah untuk menyediakan fungsi yang sama dengan mengurangi berat pada komponen. Fungsi ini bisa terintegrasi misalnya, secara bersamaan membutuhkan armor serta dukungan struktural, perlindungan jenis EMI, perlindungan petir, dan perangkat keras komunikasi. Kemajuan dalam bahan, desain,dengan teknik yang terintegrasi maka menawarkan potensi untuk menghasilkan "multifungsi" sistem komposit. Tantangan pengolahan yang jelas: setiap materi yang berpotensi memperkenalkan langkah-langkah pengolahan tambahan (dan karenanya, tenaga kerja, waktu, dan biaya). Terkait dengan pembuatan semacam ini Angkatan Darat telah memulai beberapa program untuk mengeksplorasi isu-isu tersebut. Wilayah kedua yang mempengaruhi produksi komposit adalah bahwa pemantauan kesehatan struktural (SHM). SHM adalah teknologi yang memungkinkan untuk pemeliharaan berbasis kondisidanmemiliki potensi untuk mengurangi secara signifikan "biaya proses dan ownership" keseluruhan sistem pada kondisi Aplikasi. Angkatan Darat telah memanfaatkan kedua sektor akademik dan industri untuk mulai mengidentifikasi jenis teknologi proses yang akan sesuai untuk diterapkan dan menghubungkan jenis menjanjikan SHM sensor hardware yang saat ini sedang dikembangkan. Mentis Sciences Inc telah mengembangkan sistem pakan serat yang sangat baru yang mereka telah terintegrasi dengan rudal teknologi fabrikasi radome (Gambar 6). dasarnya, teknik ini menggunakan teknik rajutan untuk kedua membentuk komponen radome struktural dan sekaligus dengan tingkat akurasi yang tinggi serangkaian sensor serat optik. Penggunaan sensor tersebut pemantauan kesehatan struktural dalam struktur rudal memiliki potensi untuk menilai kerusakan komponen rudal selama transportasi, penggunaan, dan penyimpanan.

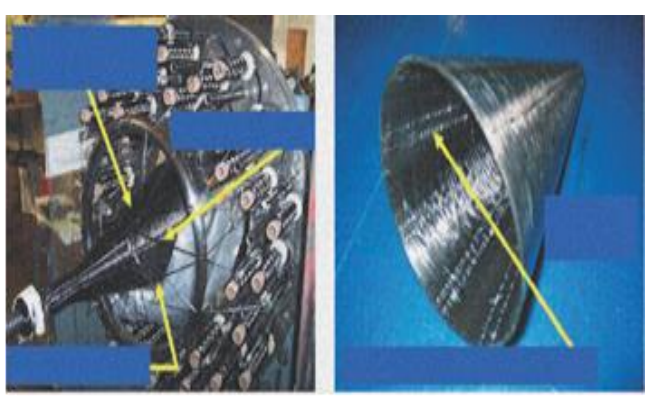

Gambar 6. Proses Jalinan Sensor Pemantauan Embedding Struktural Kesehatan

Sebuah wilayah ketiga adalah bahwa integrasi komponen multicanggih. Kajian dan program sebelumnya telah menunjukkan bahwa pengurangan berat komponen mencapai $10-20 \%$ dan pengurangan biaya fabrikasi hingga $30-50 \%$, hal tersebut mungkin jika teknologi baru dapat dikembangkan untuk mengurangi atau menghilangkan jumlah pengencang dan sistem lampiran mekanik saat ini yang digunakan dengan penggunaan dari bahan komposit. Pengeboran lubang baut ke komposit tidak hanya mengurangi daya dukung beban struktur namun juga untuk 
meningkatkan biaya produksi secara keseluruhan karena mesin, pembersihan, instalasi pengikat, dan langkah-langkah perakitan. Perlakuan untuk masalah ini adalah dua kali lipat: (1) desain yang lebih baik yang dapat meminimalkan atau menghilangkan kebutuhan untuk pengencang mekanis tradisional; (2) proses dan ikatan teknologi baru yang kompatibel dengan bahan komposit. Sebagai contoh, angkatan darat sedang mengembangkan konsep"tentara sebagai sistem" dan dengan demikian akan membutuhkan tidak hanya bahan perlindungan balistik yang lebih massal yang efisien, tetapi juga berbagai hardware untuk menjadi permanen dan sementara melekat pada shellhelm (Gambar 8). Hal ini telah mendorong eksplorasi thermoplastic- berbasis material komposit. Helm tradisional telah dibuat dengan resin thermoset-phenolic yang memiliki kekuatan mekanik serta tahan peluru. Selain peningkatan kinerja balistik, bahan termoplastik (seperti termoset) dapat dileburkan dan didaur ulang beberapa kali.

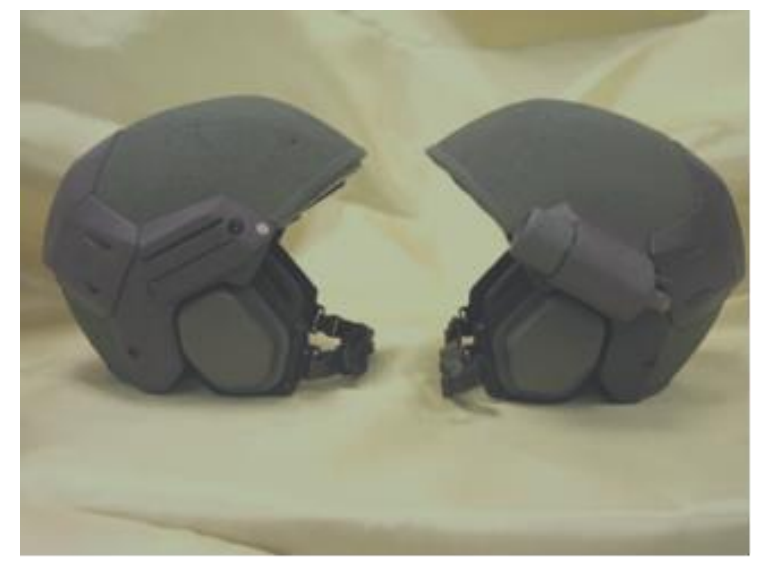

Gambar 7. Termoplastik Bonding Teknologi Terapan untuk Prototype SystemHelmet

\section{PENUTUP}

Teknologi deformasi plastik berat seperti ECAP, HPT dan ARB telah dikembangkan di berbagai bidang, terutama untuk aplikasi militer, teknologi SPD seperti ECAP, HPT Maupun ARB merupakan teknologi masa depan untuk segala macam komponen produk, terutama untuk aplikasi alat utama system pertahanan (ALUTSISTA). Semua teknologi SPD merupakan transisi teknologi konvensional terhadap teknologi canggih sehingga khusus untuk penerapan dalam bidang peralatan militer membutuhkan sifat mekanik yang tinggi dengan proses manufaktur yang ditunjang dengan kecanggihan teknologi yang mampu meminimalisir proses biaya dan ramah lingkungan. Persyaratan tersebut mampu dipenuhi oleh material komposit, dengan berat yang ringan dan sifat mekanik yang tinggi maka sangat sesuai untuk aplikasi dibidang peralatan militer.

\section{UCAPAN TERIMA KASIH}

Penulis mengucapkan terima kasih kepada; Direktur Jenderal Pendidikan Tinggi (DIKTI) Pemerintah Republik Indonesia dan Team: Prof. Renno Vinthal, Dr. Lembit Kommel dan Dr. Lauri Kollo. Laboratorium Powder Metalurgi Departement Materials Engineering Tallinn University of Technology Estonia.

\section{DAFTAR PUSTAKA}

[1] A. Azushima, R. Kopp, A. Korhonen, D.Y. Yang, F. Micari, G.D. Lahoti, P. Groche, J. Yanagimoto, N. Tsuji i, A. Rosochowski, A. Yanagida., Severe plastic deformation (SPD) processes for metals, CIRP Annals-2008. Manufacturing Technology 57: 716-735.

[2] Valiev RZ, Langdon TG. Principles of equal-channel angular pressing as a processing tool for grain refinement. 2006. Prog Mater Sci 51: 881-981.

[3] R.Z. Valiev, R.K Jslamgaliev and N.K. Tsenev. 1997. Final Technical Report United States Army CONTRACT NUMBER: 6817197-C-9006 EUROPEN RESEARCH OFFICE.

[4] Kris A Darling, Demonstration of UltrahighStrength Nanocrystalline Copper Alloys for Military Applications. 2012. Project Number: WP-2139.

[5] Hossein Akbari beni, Morteza Alizadeh, Mohammad Ghaffari, Rasool Amini, Investigation of grain refinement in $\mathrm{Al} / \mathrm{Al} 2 \mathrm{O} / \mathrm{B} 4 \mathrm{C}$ nano-composite produced by ARB. 2014. Composites : Part B 58: 438442.

[6] Radu Comaneci , Luchian Zaharia, and Romeu Chelariu, Damaging Prediction of Difficult-to-Work Aluminum Alloys During Equal Channel Angular Pressing. 2012. Journal of Materials Engineering and Performance Volume 21 (3): 287-297

[7] Megumi Kawasaki, Yi Huang, Cheng Xua, Minoru Furukawa, Zenji Horita, Terence G. Langdon. A quantitative study of cavity development in the tensile testing of an aluminum metal matrix composite processed by equal-channel angular pressing. 2005. 
Materials Science and Engineering A 410411 402-407.

[8] I. Sabirov, O. Kolednik and Reinhard Pippan, Homogenization of Metal Matrix Composites by High-Pressure Torsion. 2005. Mettalurgical and Materials Transaction A, Vol 36A: 2861-2870.

[9] X. Sauvagea, G. Wilde, S.V. Divinski, Z. Horita, R.Z. Valiev, Grain boundaries in ultrafine grained materials processed by severe plastic deformation and related phenomena. 2012. Materials Science and Engineering A 540: 1- 12.

[10] R. Derakhshandeh. H, A. Jenabali Jahromi, An investigation on the capability of equal channel angular pressing for consolidation of aluminum and aluminum composite powder. 2011. Materials \& Design Volume 32, Issue 6: 3377-3388.

[11] Shawn Walsh, Michael Maher, Suresh G. Advani, Manufacturing a more affordable ARMY through low cost composite processing, Army Material Research, Transforming Land Combat Through New Technologies AMPTIAC Quarterly. 2004. Vol 8 number 4: 42-48.

[12] Agus Pramono, Lauri Kollo, Kaspar Kallip, Renno Veinthal and J.K Gommon. Heat Treatment of Ultrafine Grained HighStrength Aluminum Alloy. 2014. KeyEngineering Materials Vol 604: 273-276

[13] N. Tsuji, Y. Saito, H. Utsunomiya and S. Tanigawa, Ultra-fine Grained Bulk Steel Produced By Accumulative Roll Bonding Process. 1999. Scripta Materialia, Vol. 40, No. 7: 795-800.

[14] Bing Q. Hana, Terence G. Langdon. Achieving enhanced tensile ductility in an Al6061 composite processed by severe plastic deformation. 2005. Materials Science and Engineering A 410-411: 430-434.

[15] I. Sabirov, O. Kolednik, and R. Pippan, Homogenization of Metal Matrix Composites by High-Pressure Torsion. 2005. Metallurgical and Materials Transactions A Vol 36A: 28612870.

[16] Mostafa Alizadeh, Milad Talebian. Fabrication of Al/Cup composite by accumulative roll bonding process and investigation of mechanical properties. 2012. Materials Science \& Engineering A 558: 331 337.

[17] Shawn Walsh, Michael Maher,Suresh G. Advani, The AMPTIAC Quarterly. 2004. Volume 8, Number 4: 43-48.

[18] Roger. N Mcdermott. Russia Conventional Military Weakness and
Substrategic Nuclear Policy. Department of the Army, Department of Defense, or the U.S. government, (2012) 4-28. 